\title{
Another Key Consideration for Facilitating Effective and Efficient Transformational Change - Lessons from the South African Department of Correctional Services
}

\author{
Mbongeni A. Mdletye \\ Jos Coetzee
}

Wilfred I. Ukpere

\author{
Department of Industrial Psychology and People Management, Faculty of Management \\ University of Johannesburg, Johannesburg, South Africa \\ E-mail: wilfredukpere@gmail.co, mbongeni@telkomsa.net
}

Doi:10.5901/mjss.2014.v5n3p190

Abstract

This study focused on establishing the identity of the South African Department of Correctional Services as an organisation during the implementation of the transformational change, which entailed a paradigm-altering culture change from the punitive to the rehabilitative philosophy in terms of the treatment of sentenced incarcerated offenders. The treatise presents empirical evidence gathered from the correctional officials based at the regional office, management area offices, and correctional centres of the Department of Correctional Services in the KwaZulu-Natal Province. According to Labich (1994), organisational identity stands at the centre of corporate failure and yet, very little empirical research has been conducted on organisational identity. De Geus (1997) concurs with Labich (1994) on the importance of organisational identity in organisational life when emphasising that organisational identity plays a significant role in promoting long-living organisations, but no extensive empirical studies have been undertaken on organisational identity. Therefore, the lack of empirical evidence on the importance of the notion of organisational identity within an organisational environment has motivated the authors to undertake an empirical study which sought to establish and explore the identity of the Department of Correctional Services of South Africa during the process of transformational change (herein refered to as the DCS change). This was an important study given the fact that arguments have been advanced to the effect that organisational identity is related to other organisational variables such as organisational culture, organisational cohesion, organisational stability, organisational loyalty, organisational commitment, organisational health, organisational functioning, organisational effectiveness, organisational efficiency, organisational sustainability, and organisational change. This study was intended to benefit managers in both the public and private sector organisations globally and particularly in South Africa, where organisations are currently engaged in massive transformational change efforts as a result the government's programme of reconstruction and development of the South African society. For purposes of contextualising the notion of organizational identity within the Department of Correctional Services and South Africa in general, an extensive literature study was undertaken. The literature study was followed by the empirical study whereby data was collected by means of a survey questionnaire from correctional officials. The empirical findings pointed to the fact that the Department of Correctional Services portrayed a negative organisational identity during the process of transformational change.

Keywords: Organisational culture, personal identity, organisational identity, group identity, corporate identity, organisational identification, organisational image, organisational reputation, organisational behaviour, organisational health, organisational life, organisational sustainability, organisational functioning, organisational loyalty, organisational commitment, organisational effectiveness, organisational efficiency, organisational cohesion, organisational stability, organisational decline, organisational change, transformational change, change management.

\section{Introduction and Background}

The notion of organisational identity and the role it plays in organisational life has emerged as a new area of interest and focus in organisation development research. There is a claim by organisation development scholars, organisational change researchers, and industrial psychologists that organisational identity is related to organisational performance (Van Tonder, 1999; Van Tonder \& Lessing, 2003; Sugreen, 2010). Organisational identity is related to other organisational variables such as organisational culture, organisational cohesion, organisational stability, organisational 
loyalty, organisational commitment, organisational health, organisational functioning, organisational effectiveness, organisational efficiency, organisational sustainability, and organisational change. Van Tonder (1999) points out that organisation identity is related to several critical organisational variables, including organisational culture, institutional focus, organisational lifecycle and organisational performance. An empirical study conducted by Sugreen (2010) on the relationship between organisational identity and organisational performance corroborated and re-emphasised Van Tonder (1999) and Van Tonder and Lessing (2003)'s assertion that there is a significant relationship between organisational identity and organisational performance, as a strong, positive, and enduring organisation identity is a critical requirement for establishing, developing and maintaining living organisations. According to McCuddy (2003), Lawler and Worley (2006), Mullins (2010), and Ackerman (2010), organisational identity exerts an influence on many factors that account for the success of organisations, including the change phenomenon in terms of its management.

For Ackerman (2000), the notion of organisational identity is a catalyst for change. For this reason, no organisation can afford to have multiple identities (Ackerman, 2000), as this would impact negatively on transformational change efforts designed to enhance organisational performance in terms of effectiveness and efficiency. Therefore, an organisational identity becomes one of the beacons that keep any transformational change effort on track. Other studies have found that a positive organisational identity is critical in promoting co-operation (Tyler, 1999), commitment (GoldenBiddle \& Rao, 1997), and identification with the organisation (Elsbach \& Bhatlacharya, 2001). This view is further strengthened by the assertion that perceptions of organisational identity have an influence on how organisational members interpret and adapt to organisational change (Corley \& Gioia, 2004; Beech \& Johnson, 2005). There is an argument by Frahm and Newton (2007) that employees who identify with the corporate identity are more open to change than employees who do not identify with the corporate identity. The lack of organisational commitment can easily lead to organisational members developing a sense of organisational change cynicism, which denotes a negative attitude towards one's employing organisation (Brown \& Cregan, 2008). It should be remembered that trust involves faith and confidence in the intentions and behaviours of fellow organisational members.

The issue of trust as a catalyst or stimulus for facilitating change is also emphasised by (Tanner, 2010; Adenle, 2011) who argues that meaningful organisational change does not occur within an organisational climate of mistrust. Without an organisational climate of mutual trust but mistrust, organisational change efforts would be doomed to failure. People's perceptions of an organisation's identity influence their interpretation and adaptation to transformational change initiatives (Corley \& Gioia, 2004; Beech \& Johnson, 2005). Witting (2006) and Cole and Bruch (2006) point out that employee behaviour plays a critical role in attaining organisational objectives. And employee behaviour is, in turn, influenced by the strength of an organisation's identity and the employee's identification with the organisation. Ran and Duimering (2007) concurs with this view when emphasising that an organisational identity does influence stakeholder behaviour and organisational performance. A negative organisational identity, does not foster co-operation, commitment, and identification with the organisation and its objectives on the part of employees. As Puusa and Tolvanen (2006) puts it that a stronger employee identification with the organisation results in stronger commitment to the organisation and what it stands for and hopes to achieve.

Therefore, based on the above argument, it can be inferred that the organisation identity variable does also play a critical role in the transformational change implementation process in terms of facilitating or hampering effective and efficient change implementation. A strong, positive, and enduring organisation identity which is underpinned by loyalty, commitment, unity, co-operation, collaboration, and strict adherence to organisational values can contribute immensely to the effective and efficient facilitation of transformational change efforts, thereby leading to change implementation success. On the other hand, a weak, negative, and crumbling organisation identity which is characterised by disloyalty, disunity, conflict, fragmentation, non-co-operation, lack of commitment, negation of organisational values can hinder the effective and efficient implementation of transformational change initiatives, thereby contributing to the high failure rate in change implementation, as highlighted by Hattingh (2004), Coetzee and Stanz (2007), Alvesson and Svenningsson (2008), Aiken and Keller (2009). Turner, Hallencreutz and Haley (2009), Turner (2011).

\subsection{Problem statement}

The low success rate in change implementation coupled with inadequate literature on the critical role that the notion of organisation identity plays in enhancing organisational performance in terms of effectiveness and efficiency, as well as the lack of technical know-how on the part of managers regarding the relationship between organisational identity and organisational performance reflects the magnitude of the challenges facing organisational change scholars and managers within the realm of organisation transformational change management. 


\subsection{Objectives}

The objectives of this paper are the following:

- To highlight that organisational identity plays a fundamental role in enhancing organisational performance in terms of effectiveness and efficiency and as such, organisational identity is a critical requirement for ensuring effective and efficient organisations;

- To underline the relationship between organisational identity and organisational performance as part of emphasising the significant role that the notion of organisational identity plays in promoting organisational effectiveness and efficiency;

- To emphasise the relationship between organizational identity and other organizational variables such as organisational culture, organisational health, organisational commitment, organisational functioning , organisational change, and organisational sustainability;

- To highlight the contribution that the notion of organisational identity might make towards the success or failure of organisational change efforts, thereby enrolling organisational identity as one of the key influential factors when it comes to change implementation;

- To highlight the negative impact that a weak and negative organisational identity might have on organisational functioning in general and more specifically when it comes to the implementation of transformational change interventions; and

- To emphasise the importance of managers in developing and maintaining, through decisive managerial intervention and action, a strong, positive, and enduring organisational identity.

\subsection{Significance and contributions of the study}

The findings of the study will be of great benefit to managers in both public and private sector organisations in South Africa and globally, as the findings will expand the existing knowledge base on the importance of developing and maintaining a strong, positive, and sustainable organisational identity as well as the relatedness of organisational identity to organisational functioning and more particularly to organisational change, through adding more empirical evidence. The treatise will certainly benefit change implementers, change recipients, change agents, and organisation development practitioners by enhancing their knowledge and skills on how to manage an organisation's identity, particularly during transformational change implementation process. The paper will be of great interest and value to managers within the Department of Correctional Services of South Africa who are charged with the responsibility of implementing, institutionalising, and sustaining the fundamental culture change from the punishment-oriented philosophy to the rehabilitation-focused philosophy in terms of the treatment of offenders, which is underpinned by various transformational change interventions such as the Offender Rehabilitation Path (ORP), the Reading for Redemption Campaign, and the Victim-Offender-Dialogues (VOD). The value that this article would add to organisation development and change management literature would be its emphasis on the relationaship between organisational identity and organisational functioning. The paper has also highlighted the importance of managerial intervention in maintaining a strong and positive organizational identity during the transformational change process.

\section{Literature Study on Organisational Identity}

According to Albert, Ashforth and Dutton (2000), it is critical for organisations to know who or what they are or are not in relation to other organisations and this is necessary so that organisations are able to perform effectively and efficiently at all levels - individual, team, and organisational levels. Furthermore, the importance of the notion of organisational identity lies in the fact that an organisation must have an identity in order for its employees to identify with the organisation what is referred to as organisational identification. Therefore, there is relationship between organisational identity (what the organisation is) and organisational identification (organisational members' association with the organisation). What the concept of organisational identity denotes is dealt with below.

\subsection{Description of organisational identity}

Albert and Whetten (1985), Holzinger and Dhalla (2004), and Whetten (2006) define organisational identity as the focal, inner, core, unique and sustainable character of an organisation. According to Whetten (2006), organisations define who 
they are through the articulation of mission, vision, value and goal statements. As indicated above, any organisation is supposed to function at three levels namely individual, team or group, and organisational levels and as such, organisational identity becomes people's view of what the organisation is from the individual, group or organizational perspective. Based on the fact that an organisation functions at the three levels mentioned above, the notion of identity also finds its meaning at these three levels and as such, the following forms of identity: personal identity, group identity, organisational identity, and corporate identity are worth noting for purposes of this study.

\subsection{Forms of identity}

- Personal identity - this refers to who the person is and as such, it can be said that personal identity denotes and reflects the distinctiveness and incomparability of the person as influenced by a person's beliefs, attitude, behaviour, values, traditions, principles, character, personality, self-concept, and group membership.

- Group identity - this denotes who the group of people is and as such, it can be argued that group identity represents the uniqueness, discreteness and character of the group as shaped by its beliefs, attitudes, behaviours, values, traditions, and principles held by people as members of the group.

- Organisational identity - this signifies people's view of the organisation in relation to its mission, vision, goals, values, niche, and branding and this view of the organisation points to people's relationship with the organisation within the internal environment.

- Corporate identity - this indicates people's view of the organisation in relation to the external organisational environment. It is for this reason that Hatch and Schultz (1997) points out that corporate identity is concerned with the external image that the organisation portrays in terms of marketing through branding and messages.

\subsection{Relationship between organisational identity and organisational functioning}

It is common knowledge that organisational goals are achieved with and through people and as such, it can be said that employees, as organisational members, stand at the centre of organisational functioning. It can be further argued that the realisation of organisational goals depends largely on the behaviour of employees. Therefore, it is important for employee behaviour to be influenced positively so that it contributes to the enhancement of organisational performance in terms of effectiveness and efficiency. O'Reilly and Chatman (1986), Ashforth and Mael (1989), Dutton, Duckerich and Harguail (1994) Hatch and Schultz (2000), and Albert, Ashforth and Dutton (2000) regard organisational identity as a basis for employee identification with the organisation and organisational identification, in turn, has the ability to affect both employee satisfaction, employee behaviour, and organisational effectiveness and efficiency positively and negatively. For this reason, it can be argued that both organisational identification and organisational identity have a considerable impact on organisational behavior at individual, team, and organisational levels and consequently on the organisational functioning and the achievement of organisational objectives at individual, team, and organisational levels.

It is important for managers to note that employee behaviour is influenced by the strength of organisational identity and employee identification with the organisation. The stronger the organisational identity, the stronger employee identification with the organisation becomes, and the more positive employee behaviour towards the organisation becomes. On the other hand, it can be argued that the weaker the organisational identity, the weaker employee identification with the organisation becomes, and the more negative employee behaviour towards the organisation becomes. Therefore, a stronger organisational identity develops a conducive organisational environment for positive employee identification and positive employee behaviour, thereby leading to a positive impact of organisational performance in terms of effectiveness and efficiency; while a weaker organisational identity provides a fertile ground for negative employee identification and negative employee behaviour, thereby contributing to organisational cynicism which impacts negatively on organisational effectiveness and efficiency at all levels of the organisation - individual, team and organisational. It is on the basis of the foregoing that Albert, Ashforth and Dutton (2000), Van Tonder (1999), Van Tonder and Lessing (2003), McCuddy (2003), Lawler and Worley (2006), Mullins (2010), and Ackerman (2010) regard organisational identity as playing a critical and fundamental role in the functioning of an organisation. An empirical study conducted by Sugreen (2010) also pointed to the existence of a causal relationship between organisational identity and organisational functioning in terms of various organisational variables.

According to Albert and Whetten (1985), the loss of an organisation's identity, which is underpinned by a vibrant organisational culture, organisational values, mission, vision, and goals, has a significant impact on the organisation and as such, it may affect the implementation, institutionalisation, and sustenance of organisational change initiatives 
negatively. Albert and Whetten (1985) point out that the loss of organisational identity has such a profound effect on the organisational change process that it may even be difficult to commence with the implementation of organisational change. This is so because the features of organisational identity constitute critical components of organisational life which serve as a guide in terms of daily operations, activities, and the behaviour of organisational members. It is for this reason that Dutton and Dukerich (1991) and Gustafson and Reger (1995) regard organisational identity as a possible source of resistance to change. Dutton and Dukerich (1991) and Elsbach and Kramer (1996) explain where this resistance to change comes when they point out that organisational identity provides both managerial and nonmanagerial members of the organisation with a critical lens through which interpretation and sensemaking of events, including organisational change, occurring within organisations is undertaken. Given what is suggested by Eby, Adams, Russell and Gaby (2000), Worrall and Cooper (2004), and Vithessonthi (2007) that people perceive and attribute meaning (characterisation) to change events and processes differently, it can be concluded that organisational identity (strong or weak) plays a critical role in influencing people's perception of change events. It is for this reason that Dutton and Dukerich (1991) argues that the outcome of people's interpretation and sensemaking of organisational events directs people's behaviours and actions within the organisation, thereby leading to either the acceptance or rejection of organisational events, including organisational change initiatives. This suggests that organisational identity does have an influence on people's decision-making insofar as organisational events are concerned, including organisational change interventions. This further implies that organisational identity does serve as a frame of reference for people within organisations to make sense of the implementation of organisational change efforts. Therefore, it can be concluded that organisational identity can serve as a critical steppingstone to achieve successful organisational change in terms of implementation, institutionalisation, and sustenance.

The argument presented above points to the fact that organisational identity is related to knowledge, attitudes, and behaviours regarding the goals of organisations, which goals also relate to organisational change. The argument also suggests that the strength of organisational identity is related to knowledge, attitudes and behaviuors regarding the goals of organisations. This implies that a strong organisational identity is related to strong and positive knowledge, attitudes, and behaviours on the part of organisational members regarding the goals of their organisation; while a weak organisational identity is related to weak and negative knowledge, attitudes, and behaviours on the part of organizational members regarding the goals of their organisation. It can therefore be discerned from the foregoing that a strong and positive organisational identity has a positive influence on knowledge, attitudes, and behaviours of organisational members regarding the organisational objectives; while a weak and negative organisational identity exerts a negative influence on people's knowledge, attitudes, and behaviours regarding organizational objectives. Therefore, stronger the organisational identity, the better the knowledge, attitudes and behaviours of organisational members regarding the organisational objectives. The weaker the organisational identity, the worse people's knowledge, attitudes, and behaviours become regarding the goals of the organisation.

\subsection{Cornerstones of organisational identity}

It was earlier indicated that it is important for organisations to have not only a unique organisational identity, but an enduring one as well. For organisational identity to be sustainable, there are forerunners that serve as cornerstones of organisational identity and these are mentioned below.

\subsubsection{Perceived organisational support}

One of the cornerstones of organisational identity is perceived organisational support or what Edwards and Peccei (2010, p. 17) refers to as "the extent to which individuals believe that their employing organisation values their contribution and cares for their well-being". Edwards and Peccei (2010) point out that when organisation shows that it cares about and for organisational members' well being, people develop an attachment to, and identification with, the organisation.

\subsubsection{Organisational involvement}

The second touchstone of organisational identity is organisational involvement, which is measured in terms of the participation of organisational members in organisational activities. Therefore, one can argue that there is a relationship between perceived organisational support and organisational involvement. 


\subsubsection{Satisfaction of needs}

Functionalists argue that people who are members of social institutions have physiological needs which must be met. People experience more job satisfaction and consequently satisfaction with the organisation if and when their goals and needs are fulfilled. This suggests that the needs of employees, as members of organisations, must be met if job satisfaction and satisfaction with the organisation is to be experienced. This further implies that people will identify more with the organisation and exert a more positive influence on the identity of the organisation when their needs are satisfied.

\subsubsection{Perceived fairness}

The perception of fairness serves as a key catalyst in motivating people to identify themselves more with their organisation. Organisational members will have positive influence on the identity of their organisation if perceived fairness is evident in the employer-employee relationship. If perceived fairness is not evident in the employer-employee relationship, employees will exert a negative influence on organisational identity (Edwards \& Peccei, 2010).

\subsubsection{Organisational prestige}

The third antecedent to organisational identity is the organisation's prestige. Mael and Ashforth (1992) and Bergami and Bagozzi (2000) empasise that when the organisation is held highly by external stakeholders, organisational members enjoy the glory as well by identifying themselves with the good reputation of the organisation, and this pushes them to identify themselves more with the organisation and its goals. When organisational members identify themselves with the organisation's reputation, the ideals that the organisation stands for become their own ideals (Bergami \& Bagozzi, 2000).

\subsubsection{Organisational communication}

Open channels of communication between the employer and employees serves as impetus for the promotion of a positive organisational identity. According to Bartels, Peters, de Jong, Pruyn and Van der Molen (2010), if and when employers have open organisational communication with employees, this will serve as effective means of conveying essential information to their employees which will foster more organisation-employee identification, thereby exerting a positive influence on organisational identity. Various types of communication such as horizontal and vertical communication are essential to ensure a positive, strong and enduring organisational identity.

\subsubsection{Congruency between personal and organisational goals and values}

According to Hall, Schneider and Nygren (1970), the notion of individual autonomy and self-fulfillment does contribute to high organisational identity. Employees who feel that the jobs they perform complement their personalities are bound to identify more with those jobs and consequently with their organisation at large which provides them with the jobs that they find autonomy and self-fulfillment in. This points to the fact that correspondence between personal and organisational goals and values leads to job satisfaction on the part of employees and as such, this job satisfaction, which derives from employees enjoying their work because they like it, increases people's identification with not only their jobs but their organisation as well, thereby contributing to the development and maintenance of a strong, positive, and sustainable organisational identity. Based on this, one can therefore conclude that the higher the congruency is between personal and organisational goals and values, the more likely that people will identify themselves with their jobs and the organisation, thereby contributing to the development and maintenance of a strong, positive and enduring organisational identity. On the other hand, it can be argued that the lower the congruency is between personal and organisational goals, the more likely that people will not identify themselves with their jobs and the organisation, thereby leading to the development and maintenance of a weal, negative and crumbling organisational identity. 


\subsection{Consequences of organisational identity}

\subsubsection{Positive Consequences}

According to O'Reilly and Chatman (1986), organisational identity is significantly related, either positively or negatively, to people's desire to remain with an organisation and as such, it can be argued that organisational identity does contribute to decreased or increased staff turnover, long or short organisational tenure, and constructive or destructive organisational behaviours. Van Dick, Grojean, Christ and Wieseke (2006) point out that there was a causal relationship between personal and group behaviour and organisational identity, which behaviours contribute to either a positive or a negative organisational identity. Bartels, Peters, de Jony, Pruyn and Van der Molen (2010) also established that employees with high organisational identity have increased job satisfaction, co-operative behavior, and lower rate of absenteeism.

\subsubsection{Negative Consequences}

Despite the positive consequences of organisational identity highlighted in the foregoing paragraph, organisational identity researchers have also found negative consequences as well in that organisational identity does exert a negative influence on other aspects of work behaviour. Umphress, Bingham and Mitchell (2010) point out that people who have high degrees of organisational identity may engage in what is referred to as unethical pro-organisational behaviour, with an employee acting unethically at on behalf of the organisation through acts of commission or omission by exaggerating or concealing information respectively. Therefore, in the light of the foregoing, it can be argued that organisational identity does provide organisational members at both managerial and non-managerial levels with a motivation to engage in unethical behaviour.

\section{Methodology}

This study utilised a two-pronged research approach, which encompassed a literature study and a quantitative empirical study. The study applied three types of research designs - exploratory design, survey design, and descriptive design.

\subsection{Sample, sampling method and population}

A random, purposive and probability samples of 1000 correctional officials and 500 offenders were utilised, which were drawn from 7593 correctional officials and 13, 520 sentenced offenders, thereby constituting $13.17 \%$ and $8.14 \%$ samples respectively.

\subsection{Research procedure}

The procedure followed in the execution of this empirical study entailed conducting a pilot study; administering the research instruments; and scoring the responses. The empirical data was collected by means of two survey questionnaires, one for correctional officials and the other for offenders. A 5-point Likert type response scale was utilised to measure the resistance-to-change behaviour on the part of correctional officials regarding the DCS transformational change.

\subsection{Statistical analysis}

The statistical analysis was conducted in two phases. Phase 1 focused on descriptive statistics with a view to providing proof that the two questionnaires used as measuring instruments were reliable and valid for the purpose of this study. To determine the adequacy and sphericity of the intercorrelation matrix, the Kaiser-Meyer-Olkin (KMO), measure of sampling adequacy (MSA) and the Bartlett's test of sphericity were conducted. A reliability analysis was also conducted on the measuring instruments with the purpose of calculating a reliability coefficient (Cronbach Alpha). Phase 2 dealt with inferential statistics through the utilisation of Structural Equation Modelling (SEM), which was employed to measure the existence of relationships between variables. 


\subsection{Response rate}

The return rate of $71.3 \%$ and the frequency rate of $98.2 \%$ for valid responses were recorded for correctional officials. For the offenders' sample, the return rate of $58.2 \%$ and the frequency rate of 97.6 for valid responses were recorded.

\subsection{Structural integrity of measuring instruments}

The inspection of the individual items on both questionnaires reveals high face validity. Regarding content validity, the contents of the questionnaire was found to be relevant to the research questions dealing with correctional officials' resistant-to-change behavior pertaining to the DCS transformational change. Concerning construct validity, it was concluded, based on results of face and content validity, that the questionnaire utilised in the study measured what it was designed to measure in terms of the resistance-to-change behaviour.

\subsection{Reliability analysis}

The suitability of data for factor analysis was assessed using the KMO measure of sampling adequacy and the Barlett's test for sphericity (Kaiser, 1970). The results of the assessment of suitability of data for factor analysis revealed that the data sets complied with the requirements of sampling adequacy and sphericity and could thus be subjected to factor analysis as the KMO MSA values for the perception and experience of DCS change variables were .942 and .939 respectively, which were highly significant because they were well above the recommended value of 0.6. (Hair, Anderson, Tatham, \& Black, 2003; Hair, Anderson, Tatham \& Black, 2006; Tabachnick \& Fidell, 2007). The Bartlett's test of sphericity values (that is, Sig. values) should be .05 or smaller. The Bartlett's test values reached statistical significance $(p=0.000)$, thereby supporting the factorability of the correlation matrices.

Regarding reliability statistics from reliability analysis, the statistics for the perception of DCS change variable reflects a Cronbach alpha coefficient of .950 from 32 items for the perception and experience of the DCS change; .854 from 11 items for the perceived nature of the DCS change (type if change); and .893 from 18 items for the perceived impact of the DCS change on the DCS as an organisation from the perspective of correctional officials. The Cronbach alpha coefficients indicate that the measuring instrument has acceptable reliability and consistency in terms of measuring the perception and experience of the DCS change, as well as the resistantce-to-change behaviour that they were designed to measure.

\section{Data Analysis and Discussion of Findings}

\subsection{Descriptive statistics of the organisational identity of the Department of Correctional Services}

Table 1 displayed below reveals that there are serious challenges regarding the identity of the Department of Correctional Services as an organisation. The negative features indicated below may in the long term impact negatively on the Department of Correctional Services' organizational identity.

Table 1. Frequency Table: The Organisational Identity of the Department of Correctional Services

\begin{tabular}{|c|c|c|c|c|c|c|}
\hline \multirow[b]{2}{*}{ Statement } & \multicolumn{6}{|c|}{ Frequency Percentages } \\
\hline & $\begin{array}{l}\text { No. } \\
\text { Valid }\end{array}$ & $\begin{array}{c}\text { No. } \\
\text { Missing }\end{array}$ & For & $\begin{array}{l}\text { No. } \\
\text { Valid }\end{array}$ & $\begin{array}{c}\text { No. } \\
\text { Missing }\end{array}$ & Against \\
\hline The DCS currently lacks a sense of unity and solidarity. & 691 & 22 & 57.3 & 691 & 22 & 33.0 \\
\hline The DCS's character is incomplete. & 687 & 26 & 50.8 & 687 & 26 & 35.4 \\
\hline The DCS is a confused organisation. & 696 & 17 & 45.5 & 696 & 17 & 43.9 \\
\hline $\begin{array}{l}\text { At this moment in time the DCS is uncertain as to who and } \\
\text { what it is. }\end{array}$ & 680 & 33 & 44.3 & 680 & 33 & 38.9 \\
\hline The DCS is a conflicted organisation. & 687 & 26 & 45.3 & 687 & 26 & 41.5 \\
\hline The DCS is searching for a clear sense of who and what it is. & 689 & 24 & 52.7 & 689 & 24 & 30.6 \\
\hline The DCS is a fragmented organisation. & 663 & 50 & 37.7 & 663 & 50 & 34.1 \\
\hline The DCS has many personalities. & 683 & 30 & 79.2 & 683 & 30 & 10.1 \\
\hline
\end{tabular}




\begin{tabular}{l|llllll}
\hline The DCS succeeded in unifying the entire workforce. & 684 & 29 & 35.8 & 684 & 29 & 45.7 \\
The DCS is experiencing a loss of character. & 681 & 32 & 49.7 & 681 & 32 & 38.5 \\
The DCS is experiencing an intense identity crisis. & 682 & 31 & 48.2 & 682 & 31 & 38.4 \\
At this moment in time the DCS is integrating different & 677 & 36 & 69.8 & 677 & 36 & 15.8 \\
personalities. & 690 & 23 & 83.8 & 690 & 23 & 8.9 \\
The DCS is a mixture of different personalities. & 679 & 34 & 41.1 & 679 & 34 & 41.9 \\
The DCS is plagued with uncertainty about what it is. & 683 & 30 & 70.4 & 683 & 30 & 12.7 \\
Who and what DCS is differs from what people think it is. & & & & &
\end{tabular}

\section{Source: Own Construction}

From Table 1 above, it is significant to note that the majority of correctional officials hold the views summarised below regarding the organisational identity of the Department of Correctional Services:

- The Department of Correctional Services currently lacks a sense of unity and solidarity;

- The Department of Correctional Services is currently working hard at developing a strong and appropriate identity or character points to the serious challenges confronting the department regarding the maintenance of a strong organisational identity;

- The character of the Department of Correctional Services is incomplete;

- The Department of Correctional Services is a confused, fragmented and conflicted organisation;

- The Department of Correctional Services is experiencing a loss of character;

- The Department of Correctional Services is a mixture of different personalities which it is still struggling to integrate;

- The Department of Correctional Services has not succeeded in unifying its workforce; and

- The Department of Correctional Services is experiencing an intense identity crisis.

Table 2. Frequency Table: The Organisational Identity of the Department of Correctional Services

\begin{tabular}{|c|c|c|c|c|c|c|}
\hline \multirow[b]{2}{*}{ Statement } & \multicolumn{6}{|c|}{ Frequency Percentages } \\
\hline & $\begin{array}{l}\text { No. } \\
\text { Valid }\end{array}$ & $\begin{array}{l}\text { No. } \\
\text { Missing }\end{array}$ & For & $\begin{array}{l}\text { No. } \\
\text { Valid }\end{array}$ & $\begin{array}{l}\text { No. } \\
\text { Missing }\end{array}$ & Against \\
\hline The DCS is a searching organisation. & 687 & 26 & 51.9 & 687 & 26 & 41.5 \\
\hline The DCS is working hard at developing a strong identity or character. & 693 & 20 & 67.3 & 693 & 20 & 27.8 \\
\hline $\begin{array}{l}\text { When compared to other institutions in the same industry, the DCS is } \\
\text { noticeably different. }\end{array}$ & 695 & 18 & 82.0 & 695 & 18 & 14.7 \\
\hline Generally, the DCS is quite unlike any other organisation. & 689 & 24 & 72.3 & 689 & 24 & 20.9 \\
\hline The DCS has many elements of a strong identity. & 692 & 21 & 55.7 & 692 & 21 & 32.1 \\
\hline $\begin{array}{l}\text { The DCS is a special institution. } \\
\text { At this moment in time, the DCS is preoccupied with its corporate }\end{array}$ & 686 & 27 & 63.4 & 686 & 27 & 26.4 \\
\hline $\begin{array}{l}\text { identity. } \\
\text { The } \mathrm{C} \text {. } \\
\text { nossesses some ouplities that could form the foundation }\end{array}$ & 680 & 33 & 53.8 & 680 & 33 & 20.7 \\
\hline a clear character. & 687 & 26 & 62.3 & 687 & 26 & 22.8 \\
\hline The DCS is a unique organisation. & 683 & 30 & 63.9 & 683 & 30 & 26.5 \\
\hline The DCS is working hard at securing an appropriate identity. & 686 & 27 & 62.9 & 686 & 27 & 22.6 \\
\hline
\end{tabular}

\section{Source: Own Construction}

As can be seen from Table 2 above, there are correctional officials who hold the view the Department of Correctional Services as an organisation does have positive features that the management cam build on to bolster and strengthen the identity of the Department. These strong aspects can be summarized as follows:

- The Department of Correctional Services is a searching organisation, continuously looking for better ways to enhance organizational effectiveness and efficiency.

- The Department of Correctional Services is working hard at developing a strong identity or character.

- When compared to other institutions within the public sector, the Department of Correctional Services is noticeably different. 
- Generally, the Department of Correctional Services is quite unlike any other organisation.

- The Department of Correctional Services has many elements of a strong identity.

- The Department of Correctional Services is a special institution.

- At this moment in time, the Department of Correctional Services is preoccupied with its corporate identity designed to improve its external organizational image.

- The Department of Correctional Services possesses some qualities that could form the foundation of a clear character.

- The Department of Correctional Services is a unique organisation.

\subsection{Organisational Identity of the DCS}

According to McCuddy (2003), Lawler and Worley (2006), Mullins (2010), and Ackerman (2010), organisational identity exerts an influence on many factors that account for the success of organisations, including the change phenomenon in terms of its management. For Ackerman (2000), the notion of organisational identity is a catalyst for change. For this reason, no organisation can afford to have multiple identities (Ackerman, 2000), as this would impact negatively on transformational change efforts designed to enhance organisational performance in terms of effectiveness and efficiency. Therefore, an organisational identity becomes one of the beacons that keep any transformational change effort on track. Contrary to the above, a very disturbing related observation or finding was that the majority of correctional official respondents (57.3\%) claimed that the Department of Correctional Services was currently lacking a sense of unity and solidarity. The second worrying related finding was that a significant percentage of correctional officials (83\%) declared that the Department of Correctional Services was a fragmented and conflicted organisation.

One of the factors contributing to disunity and lack of solidarity within the organisation is lack of trust among organisational members. This can be a barrier to any efforts to forge co-operative and collaborative links among organisational members, something that is critical for purposes of creating and strengthening support for and commitment to change. It is for this reason that trust is considered to be a critical foundation for co-operative and collaborative relationships among people within an organisational setting (Immediate Online Access, 2009). The empirical evidence from the Department of Correctional Services points to the fact that $64.7 \%$ of respondents claimed that they have partially or completely lost faith in the senior management of the Department; as opposed to $35.3 \%$ of the respondents who revealed that they have faith in the senior management. $66.9 \%$ of the respondents pointed out that there has been an increase in the distrust of top management and other officials driving the transformation process. $33.1 \%$ of the respondents held a contrary view. The above-named empirical findings should be worrying to the management of the Department of Correctional Services because they point to the fact that as long as mistrust continues to exist between executive and senior managers (change strategists and change implementers) on one hand and (nonmanagerial correctional officials (change recipients), organisational unity, which is a critical ingredient for promoting and maintaining collective and cohesive action insofar as change implementation is concerned, will remain a pipe-dream. This will consequently impact negatively on effective and efficient implementation of organisational change initiatives. It should be remembered that trust involves faith and confidence in the intentions and behaviours of fellow organisational members. The issue of trust as a catalyst or stimulus for facilitating change is also emphasised by (Tanner, 2010; Adenle, 2011) who argues that meaningful organisational change does not occur within an organisational climate of mistrust. Without an organisational climate of mutual trust but mistrust, organisational change efforts would be doomed to failure.

The foregoing argument suggests that existence of a strong sense of unity and solidarity among organisational members plays a critical role in the facilitation or promotion of support required for effective implementation of organisational change efforts. If a sense of disunity prevailing within an organisation is not addressed, managers would have difficulty in galvanising support necessary for a successful change process. Second, it needs to be emphasised that organisational disunity may negatively influence people's perception of the change process due to lack of organisational commitment on the part of organisational members. Other studies have found that a positive organisational identity is critical in promoting co-operation (Tyler, 1999), commitment (Golden-Biddle \& Rao, 1997), and identification with the organisation (Elsbach \& Bhatlacharya, 2001). This view is further strengthened by the assertion that perceptions of organisational identity have an influence on how organisational members interpret and adapt to organisational change (Corley \& Gioia, 2004; Beech \& Johnson, 2005). There is an argument by Frahm and Newton (2007) that employees who identify with the corporate identity are more open to change than employees who do not identify with the corporate identity. 
The majority of respondents (83.8 \%) revealed that Department of Correctional Services was a mixture of different personalities which it was still struggling to integrate (69.8\% of the respondents) and these multiple personalities (79.2\%) have created multiple identities which do not augur well for the effective and efficient functioning of the Department as an organisation. According to Whetten (1981), Golden-Biddle and Rao (1997) and Foreman and Whetten (2002), multiple identities exert a positive and negative impact on the organisation in terms of its functioning. The existence of multiple personal identities may pose a threat to the overarching identity of an organisation in that due to the different beliefs and values that organisational members hold, organisational members may end up displaying negative attitudes and behaviours towards their organisation, thereby leading to the development of organisational cynicism that may lead to disastrous consequences in terms of the maintenance of the organisation's identity. On the other hand, multiple identities may contribute to the effective maintenance of organisational identity as a result of having a diverse workforce that becomes united by the pursuit of common organisational goals. Therefore, different personal values, beliefs, attitudes, and behaviours may lead to different managerial and non-managerial practices and organisational culture aspects that exert positive and negative effect on the functioning of the organisation, particularly when it comes to promoting organisational identification which plays a critical role in the development and maintenance of organisational identity (Reger et al, 1994 ). It is these different personal values, beliefs, attitudes, behaviours, and actions that impact negatively or positively on organisational culture, thereby leading to the development of an appropriate or inappropriate organisational character. This tallies well with another empirical finding that the Department of Correctional Services was experiencing a loss of character or its character was incomplete and inappropriate. The foregoing underlines the critical role that organisational culture plays in creating and maintaining a vibrant, strong, positive and enduring organisational identity, as also emphasied by Ravasi and Schultz (2006) that organisational culture plays a significant role in identity threatening or identity preserving.

On the issue of the Department of Correctional Services being characterised by confusion, fragmentation and conflict, it is important to note that divisions and conflicts among organisational members affect people's morale, thereby impacting negatively on job satisfaction and consequently on work commitment and organisational commitment. It is for this reason that Brown and Cregan (2008) point out that the lack of organisational commitment can easily lead to organisational members developing a sense of organisational cynicism which would affect their individual and collective work performance negatively which would, in turn, negatively affect organisational performance. Another empirical finding worth noting relates to the fact that correctional officials have their own perceptions regarding the organisational identity of the Department of Correctional Services. The majority of respondents (70.4\% as opposed to $12.7 \%)$ believed that who and what the Department of Correctional Services is differs from what correctional officials think it is and that the Department was currently plagued with uncertainty about who and what it is (44.3\% to $38.9 \%)$. Given the findings highlighted above, it can be concluded that correctional officials are correct to point out that Department of Correctional Services was experiencing an identity crisis as a result of a loss of character. $48.2 \%$ of the respondents revealed that the Department was going through an intense identity crisis, characterised by an incomplete character 50.8) or loss of character (49.7\%).

However, despite the negative aspects referred to above, it is significant to note that the Department of Correctional Services' transformstional change agenda also includes enhancing its organisational image as part of organisational reputation management on an ongoing basis. Furthermore, the development of new vision, mission and value statements and organisational goals to guide the new strategic direction of the Department pointed to the fact that the Department was addressing its organisational identity. It is in view of this that $55.7 \%$ of the respondents believed that the Department had many elements of a strong identity and that it was currently preoccupied with its corporate identity (53.8\% of the respondents). It is also in line with the foregoing that $62.3 \%$ of the respondents believed that the Department of Correctional Services possessed some qualities that could form the foundation of a clear character. What is of concern is that the state of its organisational identity and corporate identity was being threatened by the instability characterising the Department's organisational culture. The fact that $51.9 \%$ of the respondents the Department of Correctional Services was a searching organisation, working hard at developing a strong identity or character (67.3\%) is worth noting, particularly one couples this finding with another one whereby $62.9 \%$ of the respondents pointed out that the Department of Correctional Services was working hard at securing an appropriate identity. Lastly, it needs to be highlighted that some positive comments came from the respondents, indicating that the Department of Correctional Services was a special institution (63.4\%) and unique organisation (63.9\%). 


\subsection{Implications for organisations}

The following implications can be discerned from the finding on the organisational identity of the Department of Correctional Services:

- An organisation must have an identity in order for organisational members to identify with the organisation, thereby creating the environment for organisational identification.

- The identity of an organisation influences the way the organizational members interpret organisational issues and actions; how they form their attitudes and behaviours;

- People's perceptions of an organisation's identity influence their interpretation and adaptation to transformational change initiatives (Corley \& Gioia, 2004; Beech \& Johnson, 2005);

- It is important for organisations to strive for the establishment and maintenance of positive identities. This is necessary in order to ensure that employees' perceptions of transformational change efforts are influenced in a positive manner. Witting (2006) and Cole and Bruch (2006) point out that employee behaviour plays a critical role in attaining organisational objectives. And employee behaviour is, in turn, influenced by the strength of an organisation's identity and the employee's identification with the organisation. Ran and Duimering (2007) concur with this view when emphasising that an organisational identity does influence stakeholder behaviour and organisational performance;

- A negative organisational identity, like the one of the Department of Correctional Services which is characterised by fragmentation, conflict, disunity, and lack of solidarity, does not foster co-operation, commitment, and identification with the organisation and its objectives on the part of employees. As Puusa and Tolvanen (2006) puts it that a stronger employee identification with the organisation results in stronger commitment to the organisation and what it stands for and hopes to achieve;

- No meaningful organisational change can be undertaken in an organisational climate of mistrust. This points to the fact that without an organisational climate of mutual trust, organisational change efforts would be doomed to failure. This is so because managers would find it difficult to galvanise and harness support for the change in a climate of mistrust. It is for the same reason that Paterson and Cary (2002) suggest that there is an association between employees' trust or distrust of managers, and employees' acceptance of, or resistance to, organisational change;

- Organisational disunity, lack of solidarity, organisational fragmentation, and organisational conflict may negatively influence people's perception of the change process due to lack of organisational commitment;

- Organisational culture has an effect on organisational identification and organisational commitment. This suggests that a strong organisational culture contributes to the development of a strong sense of organisational identification and organisational commitment on the part of organisational members thereby contributing to the enhancement of organisational performance in terms of effectiveness and efficiency. A weak and unstable organisational culture may lead to low morale which may, in turn, translate into reduced organisational identification and organisational commitment, thereby affecting organisational performance negatively;

- Given the above, it can be concluded that organisational identity is an antecedent of organisational identification, organisational satisfaction, organisational commitment, and organisational performance;

- Organisational identity can serve as a touchstone for organisational sustainability;

- An unstable organisational culture may impact negatively on the maintenance of a strong, vibrant, positive and enduring organisational identity;

- Organisations, in terms of organisational culture and all other actions that take place within them, have a considerable influence on the behaviors, attitudes, and actions of organisational members

- The four aspects of trust - trust in the organisation, trust in the leadership, trust in the change process, and trust in the change outcome, do affect the issue of organizational identification; and

- The issue of negative trust relationship between managers and correctional officials will in the long term affect the realization of the DCS transformational change objectives if it is not addressed urgently and decisively. The fact that the majority of correctional official participants (66.9\%) in the study indicated their loss of trust and faith in the senior management of the Department of Correctional Services is an indication that their identity as correctional officials is questionable; hence their identification with the Department as an organisation is also an issue that needs to be addressed urgently. 


\section{Conclusion}

The empirical findings captured in this paper point to the fact that in their search for different change management methodologies in order to curb and contain the high failure rate in change implementation, managers should not lose sight of the fact that the notion of organisational identity plays a critical role in organizational life in terms of the functioning of organisations. The relationship between organisational identity, organisational identification, organisational culture, organisational objectives, organisational functioning and performance, and organisational sustainability cannot be overemphasised. An organisational identity is significantly related to employees' work attitudes, behaviours, and actions which impact on their sense of organisational identification which serves as a vehicle to promote or tarnish an organisation's identity. Given the influence that an organisation's identity has on the way people perceive and interpret organisational events, including organisational change phenomenon, it is important for managers to maintain positive organisational identities through addressing people issues which end up affecting organisational harmony, organisational unity, organisational solidarity, organisational cohesion, organisational loyalty, organisational commitment, organisational health, organisational stability, organisational image and organisational sustainability in a negative sense, thereby contributing to organisational decline and organisational decay. In the light of the above, it is important for managers to understand that organisational identification and enhanced organizational performance depend on how well organisational members integrate with the organisation as a human system. Furthermore, it is critical for managers to manage organisational identification by managing how individuals form personal values and identities as influenced by organisational dynamics in terms of managerial practices and other organisational actions.

\section{References}

Ackerman, L. (2010). How identity-based management drives employee engagement and business performance. OD Practitioner, 42 (3), $36-42$. Ackerman, L. D. (2000). Identity is destiny: Leadership and the roots of value creation. San Francisco: Berrett-Koehler Publishers, Inc.

Adenle, C. (2011). Workplace change and transition. Retrieved from: http://catherinescareercorner.com on 23 March 2012.

Aiken, C. \& Keller, S. (2009). The irrational side of change management. Organization Practice. Retrieved from: http://www.google.com on 24 April 2012.

Albert, S. and Whetten, D. (1985). Organizational Identity. Research in Organizational Behavior, 7, 263-295.

Albert, S., Ashforth, B. and Dutton, J. (2000). Organizational identity and identification: Charting new waters and building new bridges. Academy of Management Review, 25(1), 13-17.

Alvesson, M. \& Svenningsson, S. (2008). Forundringnarbete I organisationer, Libes. Retrieved from: http://www.google.com on 16 July 2011.

Ashforth, B. E., \& Mael, F. (1989). Social identity and the organization. Academy of Management Review,14, $20-39$.

Bartels, J., Peters, O., de Jong, M., Pruyn, A., \& van der Molen, M. (2010). Horizontal and vertical communication as determinants of professional and organizational identification. Personnel Review, 39, 210-226.

Beech, N., \& Johnson, P. (2005). Discourses of disrupted identities in the practice of strategic change: The mayor, the street-fighter and the insider-out. Journal of Organizational Change Management, 18(1), 31-47.

Bergami, M. \& Bagozzi, R.P. (2000). Self-categorization, affective commitment and group self-esteem as distinct aspects of social identity in the organization. The British Journal of Social Psychology, 39, 555-577.

Brown, M. \& Cregan, C. (2008). Organizational change cynicism: The role of employees involvement. Human Resource Management, 47(4), 667-686.

Coetzee, C.J.H. \& Stanz, K.J. (2007). "Barriers-to-change" in a governmental service delivery type organisation. SA Journal of Industrial Psychology, 33 (2), 76-82.

Cole, M. S., \& Bruch, H. (2006). Organizational identity strength, identification, and commitment and their relationships to turnover intention: does organizational hierarchy matter? Journal of Organizational Behavior, 25 (5), 585-605.

Corley, K. G., \& Gioia, D. A. (2004). Identity ambiguity and change in the wake of a corporate spin-off. Administrative Science Quarterly, 49, 173208.

De Geus, A. (1997). The living company: Growth, learning and longevity in business. London: Nicholas Brearley Publishing.

Dutton, J. E., \& Dukerich, J. M. (1991). Keeping an eye on the mirror: Image and identity in organizational adaptation. Academy of Management Journal, 34 (1), 517-554.

Dutton, J.E., Dukerich, J.M. \& Harquail, C.V. (1994). Organizational images and member identification. Administrative Science Quarterly, 39, 239263.

Eby, L. T., Adams, D. M., Russell, J. E. A., \& Gaby, S. G. (2000). Perceptions of organizational readiness for change: Factors related to employees' reactions to the implementation of team-based selling. Human Relations, 53, 419-442.

Edwards, M.R., \& Peccei, R. (2010). Perceived organizational support, organizational identification, and employee outcomes. Journal of Personnel Psychology, 9, 17-26.

Elsbach, K. D., \& Bhattacharya, C. B. (2001). Defining who you are by what you're not: Organizational disidentification and the National Rifle Association. Organization Science, 12, 393-413.

Foreman, P. \& Whetten, D.A. (2002). Members' identification with multiple-identity organizations. Organization Science, 13 (6), 618-635.

Frahm, J.A. \& Newton, C.J. (2007). Exploring identity and change in nonprofit organizations: An employee-level perspective. In proceedings 21 st Australia and New Zealand Academy of Management Conference, University of Western Sydney, New South Wales. 
Glynn, MA. \& Witting, M. (2006). Staying the same while changing: Organizational identity in the face of environmental challenges.

Golden-Biddle, K., H. Rao. 1997. Breaches in the boardroom: Organizational identity and conflicts of commitment in a nonprofit organization. Organisation Science, 8 (Nov-Dec), 593-611.

Gustafson, L.T. \& Reger, R.K. (1995). Using organizational identity to achieve stability and change in high velocity environments. Best Papers: Proceedings of the Academy of Management. Vancouver, 464-468.

Hair, J. F., Anderson, R. E., Tatham, R.L. \& Black, W. C. (2003). Multivariate Data Analysis (5th ed.), India: Pearson Education.

Hair, J.F., Anderson, R.E., Tatham, R.L. \& Black, W.C. (2006). Multivariate data analysis. (6th ed.). Upper Saddle River, NJ: Prentice-

Hall, D.T., Schneider, B., Nygren, H.T. (1970). Personal factors in organizational identification. Administrative Science Quarterly, 15, 176-190.

Hatch, M.J. \& Schultz, M. (1997). Relations between Organizational Culture, Identity and Image. European Journal of Marketing, 31, 356-365.

Hatch, M.J. \& Schultz, M. (2002). The Dynamics of Organizational Identity. Human Relations, 55, 989-1018.

Hattingh, B. (2004). Ups and downs of mergers, acquisitions. Business Day, July 19, $1^{\text {st }}$ ed. Retrieved from: http://www.google.com on 26 June 2011.

Holzinger, I. \& Dhalla, R. (2004). The character of durability.

Kaiser, H.F. (1970). A second generation Little Jiffy. Psychometrika, 35, 401-415.

Labich, K. (1994). Why companies fail. Fortune, 130 (10), 22-32.

Lawler, E. E., \& Worley, C. G. (2006). Built to change: How to achieve sustained organizational effectiveness. San Francisco: Jossey-Bass.

Mael, F. \& Ashforth, B. (1992) Alumni and their alma maters: A partial test of the reformulated model of organizational identification. Journal of Organizational Behavior, 13, 103-123.

McCuddy, M.K. (2003). Organizational behaviour, 8e Schermerhorn, Hunt, and Osborn. John Wiley.

Mullins, L. (2010). Management and organisational behaviour. (9th ed). Essex: Pearson Education Limited.

O'Reilly, C., \& Chatman, J. (1986). Organizational commitment and psychological attachment: The effects of compliance, identification, and internalization on prosocial behavior. Journal of Applied Psychology, 71, 492-499.

Puusa, A. \& Tolvanen, U. (2006). Organizational identity and trust. 11 (2), 29-33. Retrieved from: http://www.google.com on 26 September 2012.

Ran, B. \& Duimering, P.R. (2007). Imaging the organization language use in organizational identity claims. Journal of Business and Technical Communication, 21 (2), 155-187.

Ravasi, D. \& Schultz, M. (2006). Responding to Organizational Identity Threats: Exploring the Role of Organizational Culture. Academy of Management Journal, 49, 433-458.

Reger, R. K., Gustafson, L. T., DeMarie, S. M. \& Mullane, J. V. (1994). Reframing the organization: Why implementing total quality is easier said than done. Academy of Management Review, 19, 565-584.

Reissner, S.C. (2010). Change, meaning and identity at the workplace. Journal of Organizational Management, 23 (3), $287-299$.

Sugreen, G. (2010). The relationship between organisational identity and organisational performance. Doctoral Dissertation. University of Johannesbrug, South Africa.

Tabachnick, B. \& Fidell, L. (2007). Using multivariate statistics. (5th ed). Boston: Allyn \& Bacon.

Tanner, R. (2010). Ornaizational change management: Four truths leaders should know about organizational change. Business Consulting Solutions LLC. Retrieved from: http://www.google.com on 23 August 2012.

Turner, D. (2011). The paradox of change management. Turner Change Management Inc. Dated 30 July 2011. Retrieved from: http://www.google.com on 16 July 2011.

Turner, D-M., Hallencreutz, J. \& Haley, H. (2009). Leveraging the value of an organizational change management methodology. 9th International Conference on Knowledge, Culture and Change in Boston. The International Journal of Knowledge, Culture and Change Management, 9 (9), 1-34.

Tyler, T. R. (1999). Why people cooperate with organizations: An identity-based perspective. In L. L. Cummings \& B. M. Staw (Eds.), Research in Organizational Behavior, 21, 201-246. Greenwich, CT: JAl.

Umphress, E.E., Bingham, J.B., \& Mitchell, M.S. (2010). Unethical behavior in the name of the company: The moderating effect of organizational identification and positive reciprocity beliefs on unethical pro-organizational behavior. Journal of Applied Psychology, 95, 769-780.

Van Dick, R., Grojean, M.W., Christ, O., \& Wieseke, J. (2006). Identity and the extra mile: Relationships between organizational identification and organizational citizenship behaviour. British Journal of Management, 17, 283-301.

Van Tonder, C.L. (1999). Organisation Identity: An exploratory study. Unpublished Doctoral thesis. Rand Afrikaans University, Johannesburg.

Van Tonder, C.L. \& Lessing, B.C. (2003). From identity to Organisational identity: Evolution of a concept. South African Journal of Industrial Psychology, 29 (2), 20-28.

Vithessonthi, C. (2007). Perceptions affecting employee reactions to change: Evidence from privatisation in Thailand. The Journal of American Academy of Business, 12(1), 248-255.

Whetten, D.A. (1981). Organizational responses to scarcity. Administration Quarterly, 27, 80-97.

Whetten, David A. (2006). Albert and Whetten Revisited: Strengthening the Concept of Organizational Identity. Journal of Management Inquiry,15, 219-234.

Witting, M. (2006). Relations between organizational identity, identification and organizational objectives. An empirical study in municipalities. Retrieved from: http://www.google.com on 12 February 2012.

Worrall, L. \& Cooper, C.L. (2004). Managers, hierarchies and attitudes: A study of UK managers. Journal of Management Psychology, 19 (1), $41-$ 68. 